\begin{tabular}{|c|c|}
\hline Відомості про автора: & Information about the author: \\
\hline $\begin{array}{l}\text { Iмас Свгеій Вікторович - доктор економічних } \\
\text { наук, професор, ректор Національного університе- } \\
\text { ту фізичного виховання і спорту України (Київ, } \\
\text { Україна) }\end{array}$ & $\begin{array}{l}\text { Imas Yevhenii Viktorovych - Doctor of Economics, } \\
\text { Professor, Rector of the National University of Ukrai- } \\
\text { ne on Physical Education and Sport (Kyiv, Ukraina) }\end{array}$ \\
\hline \multicolumn{2}{|l|}{ https://orcid.org/0000-0003-0641-678 } \\
\hline $\begin{array}{l}\text { Дутчак Мирослав Васильович - доктор наук з фі- } \\
\text { зичного виховання та спорту, професор, проректор } \\
\text { Національного університету фізичного виховання і } \\
\text { спорту України (Київ, Україна) }\end{array}$ & $\begin{array}{l}\text { Dutchak Myroslav Vasylovych - Doctor of Econo- } \\
\text { mics, Professor, Vice-Rector of the National Univer- } \\
\text { sity of Ukraine on Physical Education and Sport (Kyiv, } \\
\text { Ukraina) }\end{array}$ \\
\hline \multicolumn{2}{|l|}{$\begin{array}{l}\text { e-mail: mvd21@ukr.net } \\
\text { https://orcid.org/0000-0001-6823-272 }\end{array}$} \\
\hline $\begin{array}{l}\text { Андрєєва Олена Валеріївна - доктор наук з фізич- } \\
\text { ного виховання та спорту, професор, Національний } \\
\text { університет фізичного виховання і спорту України } \\
\text { (Київ, Україна) }\end{array}$ & $\begin{array}{l}\text { Andrieieva Olena Valeriivna - Doctor of Science of } \\
\text { Physical Education and Sport, Professor, National } \\
\text { University of Ukraine on Physical Education and Sport } \\
\text { (Kyiv, Ukraina) }\end{array}$ \\
\hline \multicolumn{2}{|l|}{ https://orcid.org/0000-0002-2893-1224 } \\
\hline $\begin{array}{l}\text { Кенсицька Ірина Леонідівна - кандидат наук з ф- } \\
\text { ізичного виховання та спорту, Національний уні- } \\
\text { верситет фізичного виховання і спорту України } \\
\text { (Київ, Україна) }\end{array}$ & $\begin{array}{l}\text { Kensytska Iryna Leonidivna - Candidate of Science } \\
\text { (Physical Education and Sport), Associate Professor } \\
\text { (Ph. D.), National University of Ukraine on Physical } \\
\text { Education and Sport (Kyiv, Ukraina) }\end{array}$ \\
\hline
\end{tabular}

\author{
УДК 796.035-053.9:9:616-005.4 \\ doi: 10.15330/fcult.33.10-19
}

Information about the author:

Imas Yevhenii Viktorovych - Doctor of Economics, Professor, Rector of the National University of Ukraine on Physical Education and Sport (Kyiv, Ukraina)

\title{
ОЦІККА ЕФЕКТИВНОСТІ КОМПЛЕКСНОЇ ПРОГРАМИ ФІЗИЧНОЇ ТЕРАПІЇ ХВОРИХ ЗІ СТАБІЛЬНОЮ СТЕНОКАРДІЕЮ І-ІІ ФУНКЦІОНАЛЬНОГО КЛАСУ НА ПОЛІКЛІНІЧНОМУ ЕТАПІ
}

Вивчено та проаналізовано спеціальну літературу з проблеми застосування засобів фізичної терапї в осіб при стабільній стенокардї напруження (ССН) I-II ФК. Розроблено програму фізичної терапї для хворих із ССН I-II ФК на поліклінічному етапі, яка включає лікувальну гімнастику, лікувальний масаж, фізіотерапію і дієтотерапію. Особливістю иієї програми, яка відрізняла ї̈ від традиційної програми, було включення звукової гімнастики, розширення засобів фізіотерапії завдяки впровадженню надвенного лазерного опромінення крові та ультратону вздовж хребта $i$ дотримання раціонального харчування.

Всього обстежено 33 хворих із ішемічною хворобою серия (ССН I-II ФК). Всі обстежені були чоловіками. Основну групу (ОГ) склали 16 пацієнтів із діагнозом “Іиемічна хвороба серия (ССН I-II ФК). Середній вік обстежуваних иієї групи склав $(53,6 \pm 3,5)$ роки. У групу порівняння (ГП) були відібрані 16

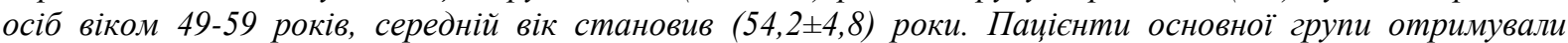
комплекс засобів фізичної терапї̈, які були розроблені в реабілітаційному відділенні поліклініки, за методикою, запропоновану В.М. Мухіним.

За результатами аналізу показників функціонування серцево-судинної системи після закінчення програм фізичної терапії встановлено вірогідне зменшення показника ЧСС в групі порівняння до $(78,4 \pm 1,6)$ уд/хв $(t=3,32 ; p<0,01)$, водночас як в основній групі аналогічні показники мали лише тенденцію до зниження $(t=1,88 ; p>0,01)$. При цььому зниження показників САТ $i$ ДАТ було більш виразним в групі пацієнтів, які отримували розроблену нами програму фізичної терапії $i$ становили, відповідно $(145,4 \pm 2,2)$ i $(84,0 \pm 2,1)$ мм рт. ст. Під впливом заходів проведеної авторської програми у пацієнтів суттєво зменшилась важкість проявів вегетативних і психосоматичних розладів, відбулось покращання загального стану, що підтверджується вірогідним ( $t=2,32$ при $p<0,05)$ зниженням величини показника вегетативного статусу за індексом Кердо до рівня $(1,03 \pm 0,02)$ балу.

Після поліклінічного етапу фізичної терапї толерантність хворих до навантажень збільшилась 8 кілька разів, число нападів стенокардї̈ зменшилося в середньому з 9 до 2-3 на добу. Запропонована ме- 
тодика фізичної терапї хворих із ССН I-II ФК безпечна, високоефективна і иілком прийнятна для такої категорії хворих.

Ключові слова: фізична терапія, сериево-судинна система, ішемічна хвороба.

The special literature on the problem of the application of physical therapy in people with stable angina effort pectoris (SAP) of FC I-II was studied and analyzed. The program of physical therapy for patients with SAP of FC I-II at the polyclinic stage has been developed, which includes medical gymnastics, therapeutic massage, physiotherapy and diet therapy. The peculiarity of this program, which distinguished it from the traditional program, was the inclusion of audio gymnastics, the expansion of physiotherapy means through the introduction of laser radiation of blood over veins and ultratone along the spine and observance of rational nutrition.

A total of 33 patients with coronary heart disease (SAP of FC I-II) were examined. All of them were men. The main group (MG) was made up of 16 patients with the diagnosis of coronary heart disease (SAP of FC I-II).

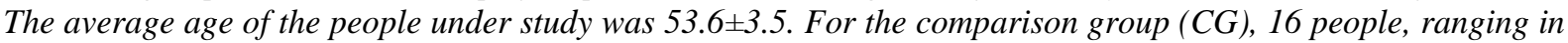

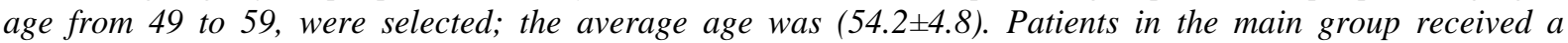
complex of physical therapy means that were developed in the rehabilitation department of the polyclinic, according to the method offered by V.M. Mukhin.

According to the results of the analysis of the cardiovascular system functioning after the end of the programs of physical therapy, a probable decrease in the heart rate index in the comparison group to $(78,4 \pm 1,6)$ beats per minute was established. $(t=3.32 ; p<0.01)$, while in the main group, similar indicators had only a tendency to decrease $(t=1.88 ; p>0.01)$. At the same time, the decrease in the indicators of systolic and diastolic blood pressure was more distinct in the group of patients who received the program of physical therapy we developed, respectively $(145,4 \pm 2,2)$ and $(84,0 \pm 2,1)$ millimetres of mercury. Under the influence of the measures taken by the author's program in patients, the severity of the manifestations of vegetative and psychosomatic disorders significantly decreased, an improvement of the general condition was observed, which is confirmed by the probable $(t=2.32$ at $p<0.05)$ decrease of the rate of the indicator of vegetative status according to the Kerdo index to the level (, $03 \pm 0.02$ ).

After the polyclinic stage of physical therapy, the tolerance of patients to physical exercise increased in several times, the number of angina attacks decreased in average from 9 to 2-3 per day. The proposed method of physical therapy for patients with SAP of FC I-II is safe, highly effective and quite acceptable for such a category of patients.

Key words: physical therapy, cardiovascular system, ischemic disease.

Постановка проблеми й аналіз результатів останніх досліджень. Ішемічна хвороба серця (IXC) це гостре і хронічне ураження серця, викликане зменшенням або зупинкою руху крові до міокарда та порушенням рівноваги між коронарним кровообігом і метаболічними потребами міокарда. Поняття “Ішемічна хвороба серця" узагальнює тільки ті патологічні процеси в міокарді, які обумовлені органічними ураженнями коронарних артерій (атеросклероз, тромбоз) або порушенням їх функціонального стану (спазм). Водночас ішемія міокарда може виникнути при ураженні вінцевих артерій серця від інших захворювань (ревматизм, інфекційний ендокардит, системний червоний вовчак і ін.), а також при вадах серця $[1,16]$.

IXC є дуже поширене захворювання. Найчастіше вона зустрічається у чоловіків у віці 40-64 років. Після 60 років частота IXC у чоловіків і жінок стає однаковою. Визначення реальної поширеності IXC має певні труднощі через мультисимптомність захворювання.

Як правило, епідеміологічні дослідження IXC базуються на виявленні стабільної стенокардії, як найбільш типової клінічної ознаки хвороби. Поширеність стенокардії суттєво зростає з віком незалежно від статі. У жінок показник поширеності складає 5 $7 \%$ у віці 45-64 роки і 10-12\% у віці 65-84 роки. У чоловіків - 4-7\% у віці 45-64 роки та 12-14\% у 65-84 роки. За офіційною статистикою 2018 р., поширеність усіх форм IXC серед дорослого населення України становить 24\%, в тому числі, серед осіб працездатного віку близько $10 \%$. Захворюваність 2\% на рік $[2,4]$. За даними світової статистики, IXC дає найвищий відсоток інвалідності та смертності серед населення $[1,8]$. Враховуючи високу актуальність такої проблеми вибору методу лікування, профілак- 
тики і відновної терапії хворим із IXC на сьогодні надається значна увага. Треба відмітити, що реабілітація хворих із IXC має свої специфічні особливості. Особливістю реабілітації при IXC є їі постійний і поетапний (фазовий) характер у зв'язку 3 необоротним хронічним процесом, яким $\epsilon$ атеросклероз коронарних артерій. Зрозуміло, що тривале активне спостереження за такими хворими створює великі труднощі. Але воно необхідне. Зрозуміло, певним стадіям хвороби повинна відповідати своя методика фізичної терапії. Цю особливість реабілітації хворих із IXC варто мати на увазі при плануванні обсягу реабілітаційної допомоги в тих або інших конкретних умовах $[5,9]$.

Зв'язок роботи 3 науковими програмами, планами, темами. Робота виконана згідно з плану науково-дослідних робіт ДВНЗ “Прикарпатський національний університет імені Василя Стефаника" та в межах комплексної наукової теми кафедри фізичної терапії, ерготерапії "Використання немедикаментозних засобів і природних факторів для покращення фізичного розвитку, функціональної і фізичної підготовленості організму”. Державний реєстраційний номер наукової теми $0117 \mathrm{U} 01745$.

Мета дослідження - розробити та впровадити програму фізичної терапії і проаналізувати iї результати у пацієнтів із ішемічною хворобою серця (стабільна стенокардія напруження I-II ФК) на поліклінічному етапі медичної реабілітації для підвищення функціональних можливостей кардіо-респіраторної системи та фізичної підготовленості і працездатності.

Методи й організація дослідження. Первинне обстеження пацієнтів із ішемічною хворобою серця (стабільна стенокардія I-II ФК) на поліклінічному етапі проводилось на 2-4 день після виписки зі стаціонару.

Для вирішення завдань дослідження застосовані наступні методи: аналіз наукової і спеціальної літератури, опитування (анкетування), функціональні проби для визначення стану серцево-судинної і дихальної систем, підготовленості та працездатності, методи математичної статистики.

Дослідження проводилося на базі міської поліклініки №2 м. Івано-Франківська. Всі обстежені перебували на амбулаторному лікуванні та спостереженні протягом 21 дня і проходили курс фізичної терапії. Всього обстежено 33 хворих із IXC (стабільна стенокардія I-II ФК). Всі обстежені були чоловіками. Основну групу (ОГ) склали 16 пацієнтів. Середній вік обстежуваних цієї групи склав $(53,6 \pm 3,5)$ року. Пацієнти основної групи отримували комплекс засобів фізичної терапії, які були розроблені в реабілітаційному відділенні поліклініки, за методикою, запропоновану В.М. Мухіним $[5,15]$. У групу порівняння (ГП) були відібрані 16 пацієнтів із стабільною стенокардією I-II ФК, середній вік яких становив $(54,2 \pm 4,8)$ року. Цим пацієнтам в подальшому проводився комплекс заходів фізичної терапії за авторською програмою, яка була узгоджена з лікарем-кардіологом (табл. 1).

Особливістю цієї програми, яка відрізняла ії̈ від традиційної програми, було включення звукової гімнастики, розширення засобів фізіотерапії завдяки впровадженню надвенного лазерного опромінення крові та ультратону вздовж хребта і дотримання раціонального харчування.

Виконання індивідуальної реабілітаційної програми нами чітко контролювалося нами і лікарем-кардіологом.

Залежно від термінів післягоспітального етапу нами запроваджувався щадний, щадно-тренувальний та тренувальний рухові режими. Фізичне навантаження на щадному, щадно-тренувальному та тренувальному рухових режимах дозувалось за складністю рухів, кількістю повторень, амплітудою та темпом виконання, особливістю масажу та дотриманням дієти. Принципами такої дієти виступали жорстко регламентова- 
на кількість калорій, дробне харчування (5-6 разів на день), обмеження в тваринних жирах, жорсткий контроль за споживанням простих вуглеводів і солі.

Таблиия 1

Індивідуальна реабілітаційна програма включала

\begin{tabular}{|c|c|c|c|c|}
\hline Дата & $\begin{array}{c}\text { Реабілітаційна } \\
\text { практика }\end{array}$ & $\begin{array}{c}\text { Кількість } \\
\text { занять }\end{array}$ & $\begin{array}{c}\text { Тривалість } \\
\text { заняття }\end{array}$ & $\begin{array}{c}\text { Місце } \\
\text { проведення }\end{array}$ \\
\hline 13.02 .19 & РГГ & 1 & 10 хв & $\begin{array}{c}\text { Палата } \\
\text { реабілітаційного } \\
\text { відділення }\end{array}$ \\
\hline 13.02 .19$. & Лікувальний масаж & 1 & 25 хв & “--===” \\
\hline 13.02 .19$. & $\begin{array}{c}\text { Надвенне лазерне } \\
\text { опромінення крові }\end{array}$ & 1 & 20 хв & “--===” \\
\hline 13.02 .19$. & Ультратон вздовж хребта & 1 & 10 хв & “--===” \\
\hline 13.02 .19 & ЛФК (комплекс №1) & 1 & 35 хв & “--===” \\
\hline
\end{tabular}

Результати і дискусія. На першому етапі у пацієнтів обох досліджуваних груп було проведено дослідження стану серцево-судинної і дихальної систем. Як видно з даних, представлених у табл. 2, у пацієнтів обох груп відмічено збільшення ЧСС. В основній групі ЧСС склала $(84,7 \pm 1,9)$ уд/хв, в групі порівняння - $(86,4 \pm 1,8)$ уд/хв. У обстежених осіб досліджуваних груп встановлено підвищені величини як систолічного, так і діастолічного АТ, що вказувало на наявність м’якої і помірної артеріальної гіпертензії.

Таблиия 2

Параметри офісного артеріального тиску і ЧСС

\begin{tabular}{|c|c|c|}
\hline Показники & Основна група (п=17) & Група порівняння (п=16) \\
\hline САТ, мм рт.ст. & $142,2 \pm 2,5$ & $145,4 \pm 2,2$ \\
\hline ДАТ, мм рт.ст & $85,0 \pm 2,3$ & $84,0 \pm 2,1$ \\
\hline ЧСС, уд./хв & $84,7 \pm 1,9$ & $86,4 \pm 1,8$ \\
\hline
\end{tabular}

Примітка: * p< 0,05 - 0,001 - достовірні зміни між нормативними показниками та показниками груп обстежених.

Так, середньогрупові значення артеріального тиску систолічного (АТс) в основній групі становили $(142,2 \pm 2,5)$ мм рт. ст., діастолічного (АТд),- $(85,0 \pm 2,3)$ мм рт. ст., а в групі порівняння, відповідно, $(145,4 \pm 2,2)$ і $(84,0 \pm 2,1)$ мм рт. ст.

Тестування функціональних резервів серцево-судинної системи здійснювали 3 використанням проб Руф’є та Руф’є-Діксона (табл. 3).

Таблиия 3

Функціональний стан серцево-судинної системи в осіб із стабільною стенокардісю I-II ФК на початку реалізації програми фізичної терапії

\begin{tabular}{|l|c|c|}
\hline \multirow{2}{*}{$\begin{array}{c}\text { Функціональні методи } \\
\text { дослідження }\end{array}$} & Контрольна група & Обстежені із IXC \\
\cline { 2 - 3 } & $\mathrm{n}=15$ & $\mathrm{n}=37$ \\
\hline Проба Руфф'є, ум.од. & $7,9 \pm 1,5^{*}$ & $15,2 \pm 2,2^{*}$ \\
\hline Проба Руфф'є- Діксона, ум. од. & $2,8 \pm 0,4^{* * *}$ & $7,2 \pm 0,6^{* * *}$ \\
\hline
\end{tabular}

Примітка:* p<0,05-0,001 - достовірні зміни між нормативними показниками та показниками груп обстежених. 
Отримані результати обстеження пацієнтів свідчать про зниження функціональних показників серцево-судинної системи у пацієнтів із СС I-II ФК у порівнянні з практично здоровими особами (табл. 2). Для прикладу, показник проби Руф’є у групі обстежуваних осіб становив $(15,2 \pm 2,2)$ ум. од., що у 1,9 разу вірогідно більше, порівняно 3 контрольною групою осіб ( $\mathrm{t}=2,37 ; \mathrm{p}<0,05)$. Працездатність серця за показниками проби Руф'є-Діксона нами розцінюється як погана, оскільки середні показники проби на $61,12 \%$ вірогідно більші, ніж в групі контролю $(\mathrm{t}=8,88 ; \mathrm{p}<0,001)$.

У табл. 4 приведені результати проб для оцінки функціональної спроможності вегетативної нервової системи.

Таблиия 4

Результати проб для оцінки вегетативного статусу у обстежених паціснтів, $(\mathbf{m} \pm \mathbf{M})$

\begin{tabular}{|r|c|c|}
\hline \multicolumn{1}{|c|}{ Показники } & Основна група & Група порівняння \\
\hline \multicolumn{1}{|c|}{ пнделя Кердо } & $1,27 \pm 0,02$ & $1,32 \pm 0,03$ \\
\hline $\begin{array}{l}\text { Проба з ізометричним навантаженням: } \\
\text { приріст ДАТ на 3 хвилині, мм рт. ст. }\end{array}$ & $1,03 \pm 0,02$ & $1,02 \pm 0,01$ \\
\hline після & $23,9 \pm 1,7$ & $24,4 \pm 2,1$ \\
\hline $\begin{array}{l}\text { Індекс Кердо } \\
\text { Проба з ізометричним навантаженням: } \\
\text { приріст ДАТ на 3-й хвилині, мм рт. ст. }\end{array}$ & $11,6 \pm 2,7$ & $16,01 \pm 1,9$ \\
\hline
\end{tabular}

Примітка:* p<0,05-0,001 - достовірні зміни між нормативними показниками та показниками груп обстежених.

У цілому, за значеннями індексу проби з ізометричним навантаженням $\mathrm{i}$ індексу Кердо констатовано значну перевагу активності симпатичної нервової системи у пацієнтів обох груп. У основній групі величина приросту ДАТ складала $(23,9 \pm 1,7)$ мм рт. ст., в групі порівняння - $(24,4 \pm 2,1)$ мм рт. ст. Вагомим аргументом на користь симпатикотонії слугують також результати обчислення I. Кердо, який був значно більшим у осіб групи порівняння. Перевищення його значення, рівного 1, засвідчує суттєву перевагу тонусу симпатичної ланки ВНС у обстежених хворих.

Повторне обстеження реконвалесцентів 3 метою вивчення функціонування серцево-судинної системи і функціональної витривалості проводилось після впровадження програм фізичної терапії протягом 21 дня. Результати обстеження серцево-судинної системи пацієнтів із СС I-II ФК після впровадження програм фізичної терапії наведені на рис.1.

За результатами аналізу показників функціонування серцево-судинної системи після закінчення програм фізичної терапії встановлено вірогідне зменшення показника ЧСС в групі порівняння до $(78,4 \pm 1,6)$ уд/хв. $(\mathrm{t}=3,32 ; \mathrm{p}<0,01)$, водночас як в основній групі аналогічні показники мали лише тенденцію до зниження $(\mathrm{t}=1,88 ; \mathrm{p}>0,01)$. При цьому зниження показників САТ і ДАТ було більш виразним в групі пацієнтів, які отримували розроблену нами програму фізичної терапії і становили, відповідно $(145,4 \pm 2,2)$ і $(84,0 \pm 2,1)$ мм рт. ст. Під впливом заходів проведеної авторської реабілітаційної програми суттєво зменшилась важкість проявів вегетативних і психосоматичних розладів, відбулось покращання загального стану пацієнтів, що підтверджується вірогідним $(\mathrm{t}=2,32$ при $\mathrm{p}<0,05)$ зниженням величини показника вегетативного статусу за індексом Кердо до рівня $(1,03 \pm 0,02)$ балу, який був статистично менший $(\mathrm{t}=1,8$ при $\mathrm{p}<0,05)$, порівно з вихідними даними (табл. 4$)$. 


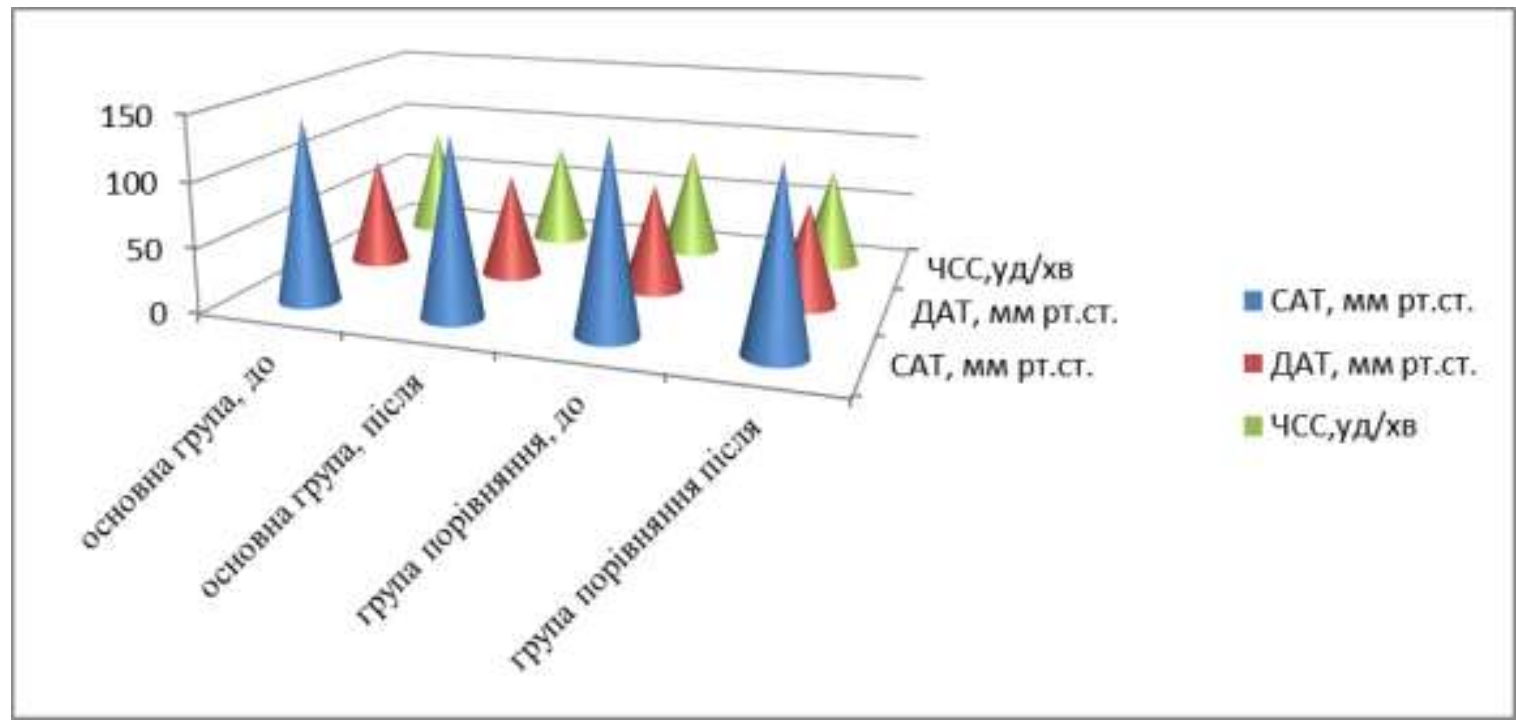

Puc. 1. Результати обстеження серцево-судинної системи у пацієнтів із стабільною стенокардією I-II ФК після впровадження програм фізичної терапії

Подальші дослідження вегетативного статусу показали, що показник ДАТ після 3-хвилинного перебування у вертикальному положенні і стискання динамометра 3 силою 30\% від максимальної (проба з ізометричним навантаженням) у хворих групи порівняння складав, у середньому, $(16,01 \pm 1,9)$ мм рт. ст., що $є$ вірогідно менше, ніж на початку дослідження $(\mathrm{p}<0,05)$. Такий результат проби оцінюється як добрий, оскільки значення показника знаходяться на верхній межі норми. У пацієнтів основної групи подібний показник встановлено на рівні $(11,6 \pm 2,7)$ мм рт. ст., що вказує на порушення вегетативного статусу у подібної категорії пацієнтів.

За результатами дослідження, індекс Руф’є у групі порівняння наприкінці дослідження становив $(8,2 \pm 1,4)$ ум. од., що у 1,87 разу є кращим, порівняно з вихідними даними $(15,4 \pm 2,32)$ ум. од., $(\mathrm{t}=2,66 ; \mathrm{p}<0,01)$ і майже досягнув показника контрольної групи - $(8,8 \pm 1,4)$ ум. од., $(\mathrm{t}=0,4 ; \mathrm{p}>0,1)$. У то й же час, середні значення показника Руф'є у основній групі наприкінці дослідження склали $(12,8 \pm 1,4)$ ум. од., що вказує тільки на задовільне функціонування серця.

Отримані середні значення показника індексу Руф'є-Діксона у обстежуваних пацієнтів групи порівняння наприкінці дослідження становили $(5,9 \pm 0,89)$ ум. од., що вказує на 13,24\% покращення і відповідає середньому рівню працездатності, і є кращими, порівняно 3 показниками основної групи пацієнтів $(6,8 \pm 1,02)$ ум. од., проте статистично недостовірними ( $\mathrm{t}=0,66 ; \mathrm{p}>0,1)$.

Для об'єктивізації функціональної здатності дихальної та серцево-судинної системи був виконаний тест із 6-хвилинною ходьбою (6MWD) і Гарвардський степ-тест. Результати проведеного дослідження у хворих обох груп представлено в табл. 5.

Внаслідок реалізації розробленої нами програми відзначено підвищення толерантності до фізичного навантаження та перехід з низької ТФН до середньої, що стверджено на підставі результатів 6-хвилинної проби та Гарвардського степ-тесту. Після поліклінічного етапу толерантність хворих до навантажень збільшилась, число нападів стенокардії зменшилося в середньому з 9 до 2-3 на добу. 
Показники функціональної витривалості паціснтів у групах дослідження на початку та в наприкінці програм фізичної терапії

\begin{tabular}{|c|c|c|c|c|}
\hline \multirow[b]{2}{*}{ Показники } & \multicolumn{2}{|c|}{ Періоди дослідження } & $\mathbf{t}$ & $\mathbf{p}$ \\
\hline & $\begin{array}{c}\text { Первинне } \\
\text { обстеження }\end{array}$ & $\begin{array}{c}\text { Після } \\
\text { дослідження }\end{array}$ & & \\
\hline \multicolumn{5}{|c|}{ Основна група } \\
\hline $\begin{array}{l}\text { Гарвардський } \\
\text { степ-тест, ум. од. }\end{array}$ & $56,8 \pm 9,8$ & $64,3 \pm 10,3$ & 0,14 & $>0,1$ \\
\hline $6 \mathrm{MWT}, \mathrm{M}$ & $268,4 \pm 34,6$ & $316,4 \pm 36,8$ & & \\
\hline \multicolumn{5}{|c|}{ Група порівняння } \\
\hline $\begin{array}{l}\text { Гарвардський степ-тест, } \\
\text { ум.од. }\end{array}$ & $56,8 \pm 9,8$ & $67,5 \pm 12,3$ & 0,81 & $>0,1$ \\
\hline 6MWT, $\mathrm{M}$ & $268,4 \pm 34,6^{*}$ & $346,4 \pm 38,4^{*}$ & 1,53 & $<0,05$ \\
\hline
\end{tabular}

Примітки: $1 .^{*}$ - різниця показників вірогідна в порівнянні з контрольною групою $(\mathrm{p}<0,05)$.

$2 .^{\wedge}$ - показник вірогідності розходжень $\mathrm{p}<0,05-\mathrm{p}<0,001$ в порівнянні з вихідними даними.

Для узагальнення результатів дослідження нами були вивчені окремі показники якості життя за опитувальником SF-36. Встановлено, що після курсу авторського варіанту фізичної терапії наступило збільшення параметру на рівні статистичної тенденції “сон/відпочинок” з $(47,8 \pm 3,4)$ до $(56,1 \pm 3,6)$ бала $(\mathrm{t}=1,68 ; \mathrm{p}<0,1)$, достовірне збільшення параметру “духовність” з $(52,3 \pm 2,1)$ до $(58,7 \pm 2,3)$ бала $(\mathrm{t}=2,05 ; \mathrm{p}<0,05)$, “фізична сфера" з $(44,0 \pm 2,5)$ до $(46,9 \pm 2,7)$ бала $(\mathrm{t}=0,79 ; \mathrm{p}>0,1)$, “психологічна сфера" 3 $(50,9 \pm 2,0)$ до $(52,5 \pm 2,1)$ бала $(\mathrm{t}=0,48 ; \mathrm{p}>0,1)$ і достовірне зниження параметру "залежність від ліків і медичної допомоги" з $(43,9 \pm 0,9)$ до $(40,8 \pm 0,8)$ бала $(\mathrm{t}=2,57 ; \mathrm{p}<0,05)$. Показник загального стану здоров'я (GF) змінився на $15,43 \%$ у сторону покращення 3 $(31,10 \pm 3,70)$ до $(35,90 \pm 4,30)$ бала $(\mathrm{t}=3,00 ; \mathrm{p}<0,01)$.

Запропонована методика фізичної терапії хворих із СC II ФК безпечна, високоефективна і цілком прийнятна для такої категорії хворих. Нам видається, що отримані результати необхідно враховувати при розробці програми реабілітаційних заходів, спрямованих на оптимізацію загального стану та функціонування серцево-судинної системи пацієнтів із стабільною стенокардією I-ІІ ФК.

\section{Висновки}

1. На початку дослідження для пацієнтів із стабільною стенокардією I-II ФК характерними є збільшення частоти серцевих скорочень, величин артеріального тиску, симпатикотонічний тип функціонування вегетативної нервової системи, зниження показників проб Руф'є та Руф'є-Діксона, тесту 6-хвилинної ходи та Гарвардського степ-тесту.

2. Запропонована нами комплексна програма фізичної терапії, яка включала поєднання корекції психоемоційного стану, засобів лікувальної гімнастики, масажу, фізіотерапії та дієтотерапії, має загальнозміцнюючу дію на фізичний розвиток, функціональний стан основних систем організму і функціональну витривалість і працездатність у осіб із стабільною стенокардією напруження I-II ФК.

3. Отримані результати дослідження можна враховувати як при діагностиці стабільної стенокардії напруження I-II ФК, так і при розробці програми реабілітаційних заходів, спрямованих на покращення психоемоційного стану і оптимізацію функціонування серцево-судинної системи.

Перспективи подальших досліджень пов'язані з розробкою та науковим обгрунтуванням введення новітніх заходів до комплексної програми фізичної терапії осіб при стабільній стенокардії напруження. 
1. Михайловська НС. Особливості ремоделювання міокарда у хворих на ішемічну хворобу серця залежно від функціонального стану щитоподібної залози. Патологія. 2015; 2(34): 17-21.

2. Олійник ТВ. Варіабельність серцевого ритму у хворих на ішемічну хворобу серця асоційовану 3 гіпофункцією щитоподібної залози. В: Смоланка В.В., укладач. Матеріали XII наук.-практ. конф. 3 міжнар. участю студентів та молодих вчених "Науковий потенціал молоді - прогрес медицини майбутнього"; 2014 квіт. 23-26; Ужгород, 2014: 210

3. Олійник ТВ. Вплив гормонів гіпофізарно-тиреоїдної системи на показники вегетативного забезпечення серцевої діяльності у хворих на ішемічну хворобу серця 3 супутньою гіпофункцією щитоподібної залози. В: Панасенко О.І., редактор. Зб. тез доп. Всеукр. наук.-практ. конф. студентів та молодих учених з міжнар. участю Сучасні аспекти медицини і фармації; 2014 трав. 15-16: м. Запоріжжя, 2014, с. 118.

4. Олейник ТВ. Особенности кардиогемодинамики у больных ишемической болезнью сердца, коморбидной с гипотиреозом. В: Кулага О.К., Барковский Е. В., редактор. Материалы 69-й науч.-практ. конф. студентов и молодых ученых с междунар. участием “Актуальные проблемы современной медицины и фармации”, 2015 апр. 15-17: Минск, 2015: 136.

5. Олійник ТВ. Структурно-функціональне ремоделювання міокарда у хворих на ішемічну хворобу серця, коморбідну з гіпотиреозом. В: Панасенко О.І., редактор. Матеріали Всеукр. наук.-практ. конф. молодих вчених та студентів з міжнар. участю “Сучасні аспекти медицини і фармації - 2015”, 2015 трав. 14-15: Запоріжжя, 2015: 103.

6. Олійник ТВ. Вплив супутнього гіпотиреозу на стан імунозапальної активації та ендотеліальної дисфункції у хворих на ішемічну хворобу серця. В: Панасенко О.І., редактор. Матеріали Всеукр. наук.практ. конф. молодих вчених та студентів “Здобутки теоретичної медицини - в практику охорони здоров’я - 2016”, 2016 бер. 24-25: Запоріжжя, 2016: 38-39.

7. Олійник ТВ. Зміни показників імунного запалення та ендотеліальної дисфункції у хворих на ішемічну хворобу серця з супутнім гіпотиреозом під впливом базисної терапії з додаванням кверцетину. В: Панасенко O.I., редактор. Матеріали Всеукр. наук.-практ. конф. молодих вчених та студентів 3 міжнар. участю “Сучасні аспекти медицини і фармації - 2016”, 2016 трав. 12-13: Запоріжжя, 2016: 128.

8. Михайловська НС. Особливості клінічного перебігу ішемічної хвороби серця у хворих з супутньою гіпофункцією щитоподібної залози. В: Шульгай А. Г., редактор. Здобутки клінічної і експериментальної медицини. Матеріали Всеукр. наук.-практ. конф. $з$ міжнар. участю “Актуальні питання діагностики, лікування, раціональної фармакотерапії, диспансеризації та реабілітації в практиці сімейного лікаря”, 2014 трав. 15-16: Тернопіль, 2014: 62.

9. Михайловська НС. Біологічні маркери прозапальної активації, дисфункції ендотелію та гіперкоагуляції у хворих на ішемічну хворобу серця та гіпотиреоз: взаємозв'язок з гормонами гіпофізарно-тиреоїдної ланки. Укр. кардіол. журн. Додаток 1 : матеріали XVI Нац. конгресу кардіологів України, 2015 вер. 23-25: Київ, 2015: 99.

10. Михайловська Н С. Взаимосвязь между гуморальными нарушениями и сруктурно-функциональными показателями сердца у больных аутоиммунным тиреоидитом с гипофункцией щитовидной железы . Укр. кардіол. журн. Укр. кардіол. журн. Додаток 1: матеріали XVI Нац. конгресу кардіологів України, 2015 вер. 23-25: Київ, 2015: 60.

11. Апанасенко ГЛ. Лечебная фізкультура при заболеваниях сердечно-сосудистой системы. Киев: Здоровье; $1987.120 \mathrm{c}$.

12. Зотов В. Введение в оздоровительную реабилитацию. Киев: Медекол; 1995. 181 с.

13. Гасилин ВС. Поликлинический этап реабилитации больных инфарктом миокарда. Москва: Медицина; 1984. $174 \mathrm{c}$.

14. Готовцев ПИ. Лечебная физкультура и массаж. Москва: Медицина; 1987. 304 с.

15. Зайцев В.П. Физическая реабилитация больных, перенесших инфаркт миокарда. Харьков: ХГИФК; $1995.147 \mathrm{c}$.

16. Комплексная реабилитация больных острым инфарктом миокарда. Курск: Б. И.; 1998. 48 с.

17. Нові аспекти лікування та реабілітації хворих на інфаркт міокарда. Київ: Укр. НДІ кардіології ім. акад. М. Д. Стражеска; 1997. 34 с.

\section{References}

1. Mykhailovska NS. Osoblyvosti remodelyuvannya miokarda u khvorykh na ishemichnu khvorobu sertsya zalezhno vid funktsional'noho stanu shchytopodibnoyi zalozy. Patolohiya. 2015; 2(34): 17-21. 2.

2. Oliinyk TV. Variabel'nist' sertsevoho rytmu u khvorykh na ishemichnu khvorobu sertsya asotsiyovanu z hipofunktsiyeyu shchytopodibnoyi zalozy. V: Smolanka V.V., ukladach. Materialy XII nauk.-prakt. konf. z mizhnar. uchastyu studentiv ta molodykh vchenykh "Naukovyy potentsial molodi - prohres medytsyny maybutn'oho"; 2014 kvit. 23-26; Uzhhorod, 2014: 2103. 
3. Oliynyk TV. Vplyv hormoniv hipofizarno-tyreoyidnoyi systemy na pokaznyky vehetatyvnoho zabezpechennya sertsevoyi diyal'nosti u khvorykh na ishemichnu khvorobu sertsya z suputn'oyu hipofunktsiyeyu shchytopodibnoyi zalozy. V: Panasenko O.I., redaktor. Zb. tez dop. Vseukr. nauk.-prakt. konf. studentiv ta molodykh uchenykh z mizhnar. uchastyu Suchasni aspekty medytsyny i farmatsiyi; 2014 trav. 15-16: m. Zaporizhzhya, 2014, s. 118. 4.

4. Oleynyk TV. Osobennosty kardyohemodynamyky u bol'nykh yshemycheskoy bolezn'yu serdtsa, komorbydnoy s hypotyreozom. V: Kulaha O.K., Barkovskyy E. V., redaktor. Materyaly 69-y nauch.-prakt. konf. studentov y molodykh uchenykh s mezhdunar. uchastyem "Aktual'nye problemy sovremennoy medytsyny y farmatsyy", 2015 apr. 15-17: Mynsk, 2015: 136. 5.

5. Oliynyk TV. Strukturno-funktsional'ne remodelyuvannya miokarda u khvorykh na ishemichnu khvorobu sertsya, komorbidnu z hipotyreozom. V: Panasenko O.I., redaktor. Materialy Vseukr. nauk.-prakt. konf. molodykh vchenykh ta studentiv z mizhnar. uchastyu "Suchasni aspekty medytsyny i farmatsiyi - 2015", 2015 trav. 14-15: Zaporizhzhya, 2015: 103. 6.

6. Oliynyk TV. Vplyv suputn'oho hipotyreozu na stan imunozapal'noyi aktyvatsiyi ta endotelial'noyi dysfunktsiyi u khvorykh na ishemichnu khvorobu sertsya. V: Panasenko O.I., redaktor. Materialy Vseukr. nauk.-prakt. konf. molodykh vchenykh ta studentiv "Zdobutky teoretychnoyi medytsyny - v praktyku okhorony zdorov'ya - 2016”, 2016 ber. 24-25: Zaporizhzhya, 2016: 38-39. 7.

7. Oliynyk TV. Zminy pokaznykiv imunnoho zapalennya ta endotelial'noyi dysfunktsiyi u khvorykh na ishemichnu khvorobu sertsya z suputnim hipotyreozom pid vplyvom bazysnoyi terapiyi z dodavannyam kvertsetynu. Panasenko O.I., redaktor. Materialy Vseukr. nauk.-prakt. konf. molodykh vchenykh ta studentiv z mizhnar. uchastyu "Suchasni aspekty medytsyny i farmatsiyi - 2016", 2016 trav. 12-13: Zaporizhzhya, 2016: 128. 8 .

8. Mykhailovska NS. Osoblyvosti klinichnoho perebihu ishemichnoyi khvoroby sertsya u khvorykh z suputn'oyu hipo-funktsiyeyu shchytopodibnoyi zalozy. V: Shul'hay A. H., redaktor. Zdobutky klinichnoyi i eksperymental'noyi medytsyny. Materialy Vseukr. nauk.-prakt. konf. z mizhnar. uchastyu "Aktual'ni pytannya diahnostyky, likuvannya, ratsional'noyi farmakoterapiyi, dyspanseryzatsiyi ta reabilitatsiyi $\mathrm{v}$ praktytsi simeynoho likarya", 2014 trav. 15-16: Ternopil', 2014: 62.9.

9. Mykhailovska NS. Biolohichni markery prozapal'noyi aktyvatsiyi, dysfunktsiyi endoteliyu ta hiperkoahulyatsiyi u khvorykh na ishemichnu khvorobu sertsya ta hipotyreoz: vzayemozv'yazok z hormonamy hipofizarno-tyreoyidnoyi lanky. Ukr. kardiol. zhurn. Dodatok 1 : materialy XVI Nats. konhresu kardiolohiv Ukrayiny, 2015 ver. 23-25: Kyyiv, 2015: 99. 10.

10. Mykhaylovs'ka N S. Vzaymosvyaz' mezhdu humoral'nymy narushenyyamy y srukturno-funktsyonal'nymy pokazatelyamy serdtsa u bol'nykh autoymmunnym tyreoydytom s hypofunktsyey shchytovydnoy zhelezy . Ukr. kardiol. zhurn. Ukr. kardiol. zhurn. Dodatok 1: materialy XVI Nats. konhresu kardiolohiv Ukrayiny, 2015 ver. 23-25: Kyyiv, 2015: 60. 11.

11. Apanasenko HL. Lechebnaya fizkul'tura pry zabolevanyyakh serdechno-sosudystoy systemy. Kyev: Zdorov'e; 1987. 120 s. 12.

12. Zotov V. Vvedenye v ozdorovytel'nuyu reabylytatsyyu. Kyev: Medekol; 1995. 181 s. 13.

13. Hasylyn VS. Polyklynycheskyy étap reabylytatsyy bol'nykh ynfarktom myokarda. Moskva: Medytsyna; 1984. 174 s. 14.

14. Hotovtsev PY. Lechebnaya fyzkul'tura y massazh. Moskva: Medytsyna; 1987. 304 s. 15.

15. Zaytsev VP. Fyzycheskaya reabylytatsyya bol'nykh, perenesshykh ynfarkt myokarda. Khar'kov: KHHYFK; 1995. $147 \mathrm{~s}$.

16. Complex rehabilitation of patients with acute myocardial infarction. Kursk: B.I. .; 1998. 48 p.

17. New aspects of treatment and rehabilitation of patients with myocardial infarction. Kiev: Ukr. Research Institute of Cardiology them. acad. M. D. Strazhesko; 1997. 34 p.

\section{Цитування на цю статтю:}

Баскевич ОВ, Герич РП, Лісовський БП, Наконечна СП. Оцінка ефективності комплексної програми фізичної терапії хворих зі стабільною стенокардією I-II функціонального класу на поліклінічному етапі. Вісник Прикарпатського університету. Серія: Фізична культура. 2019 Берез 26; 33: 10-19

\begin{tabular}{|c|c|}
\hline Відомості про автора: & Information about the author: \\
\hline $\begin{array}{l}\text { Баскевич Олег Володимирович - кандидат медич- } \\
\text { них наук, доцент, ДВНЗ “Прикарпатський націо- } \\
\text { нальний університет імені Василя Стефаника" } \\
\text { (Івано-Франківськ, Україна) }\end{array}$ & $\begin{array}{l}\text { Baskevych Oleh Volodymyrovych - Candidate of } \\
\text { Science (Medicine), Associate Professor (Ph. D.), Va- } \\
\text { syl Stefanyk Precarpathian National University (Ivano- } \\
\text { Frankivsk, Ukraine) }\end{array}$ \\
\hline $\begin{array}{l}\text { e-mail: hejlion@gmail.com } \\
\text { http://orcid.org/0000-0002-5755-5547 }\end{array}$ & \\
\hline
\end{tabular}




\begin{tabular}{|c|c|}
\hline $\begin{array}{l}\text { Герич Роман Петрович - кандидат медичних } \\
\text { наук, доцент, ДВНЗ “Прикарпатський національ- } \\
\text { ний університет імені Василя Стефаника” (Івано- } \\
\text { Франківськ, Україна) }\end{array}$ & $\begin{array}{l}\text { Herych Roman Petrovych - Candidate of Science } \\
\text { (Medicine), Associate Professor (Ph. D.), Vasyl Ste- } \\
\text { fanyk Precarpathian National University (Ivano- } \\
\text { Frankivsk, Ukraine) }\end{array}$ \\
\hline \multicolumn{2}{|l|}{ http://orcid.org/0000-0003-4527-4972 } \\
\hline $\begin{array}{l}\text { Лісовський Богдан Петрович - кандидат біоло- } \\
\text { гічних наук, доцент, ДВНЗ “Прикарпатський на- } \\
\text { ціональний університет імені Василя Стефаника" } \\
\text { (Івано-Франківськ, Україна) }\end{array}$ & $\begin{array}{l}\text { Lisovskyi Bohdan Petrovych - Candidate of Science } \\
\text { (Biology), Associate Professor (Ph. D.), Vasyl Ste- } \\
\text { fanyk Precarpathian National University (Ivano- } \\
\text { Frankivsk, Ukraine) }\end{array}$ \\
\hline \multicolumn{2}{|l|}{$\begin{array}{l}\text { e-mail: lisovsky.bogdan@ gmail.com } \\
\text { https://orcid.org/0000-0003-0474-9572 }\end{array}$} \\
\hline $\begin{array}{l}\text { Наконечна Свімлана Павлівна - аспірант, ДВН3 } \\
\text { "Прикарпатський національний університет імені } \\
\text { Василя Стефаника" }\end{array}$ & $\begin{array}{l}\text { Nakonechna Svitlana Pavlivna - post-graduate stu- } \\
\text { dent, Vasyl Stefanyk Precarpathian National Univer- } \\
\text { sity (Ivano-Frankivsk, Ukraine) }\end{array}$ \\
\hline
\end{tabular}

УДК 378.147.091.31-051:796:005.32

doi: 10.15330/fcult.33.19-26

Аліна Боднар, Юрій Юрчишин, Іван Стасюк

\section{АНАЛІЗ ДИНАМІКИ СФОРМОВАНОСТІ МОТИВАЦЙННГО КОМПОНЕНТУ ГОТОВНОСТІ МАЙБУТНІХ УЧИТЕЛІВ ФІЗИЧНОЇ КУЛЬТУРИ ДО ОЛІМПІЙСЬКОї ОСВІТИ МОЛОДШИХ ШКОЛЯРІВ}

Мета: Проаналізувати динаміку сформованості мотиваційного компоненту готовності майбутніх учителів фізичної культури до олімпійської освіти на констатувальному етапі та після завершення формувального етапу педагогічного експерименту.

Матеріал і методи: У дослідженні приймали участь 181 майбутніх учителів фізичної культури (88 студентів у складі експериментальних груп i 93 студенти контрольних груп). Для перевірки вірогідності відмінностей між рівнями готовності студентів експериментальних і контрольних груп нами використовувався критерій Пірсона $\left(X^{2}\right)$ який застосовують у непараметричних (якісних) вимірюваннях.

Отримані результати та висновки. Аналіз результатів педагогічного експерименту засвідчив, що за мотивачійним компонентом в експериментальній групі 93,2\% студентів досягнули високого $i$ середнього рівнів досліджуваної готовності проти 77,3\% на початку експерименту в той час як $у$ контрольній групі 87,1\% студентів досягли високого і середнього рівнів проти 76,3\% на початку експерименту.

Ключові слова: мотивачія, майбутні учителі фізичної культури, підготовка, олімпійська освіта.

Objectives: To analyze the dynamics of formation of motivational component of future teachers of physical education for the Olympic education at the stage of formation and after the completion of the formative stage of the pedagogical experiment.

Material and methods: 181 future teachers of physical education participated in the study (88 students in experimental groups and 93 students in control groups). The experimental groups consisted of students of the Faculty of Physical Education of Kamianets-Podilskyi Ivan Ohienko National University (40 persons) and students of Chernivtsi National University (48 persons), and the control groups included students of Ternopil Volodymyr Hnatyuk National Pedagogical University (23 persons ) and H.S. Skovoroda Kharkiv National Pedagogical University (70 persons). To test the probability of differences between the levels of readiness of students in experimental and control groups, we took into consideration the Pearson $\left(X^{2}\right)$ criterion which is used in nonparametric (qualitative) measurements.

Results and conclusions. The analysis of the results of the pedagogical experiment showed positive changes in the level of formation of the motivational component of readiness of future teachers of physical education for the Olympic education of primary schoolchildren who were part of the experimental group compared to the control group. Thus, based on the motivational component in the experimental group, 93.2\% of the students achieved high and average levels of readiness compared with $77.3 \%$ at the start of the experiment, while $87.1 \%$ of students of the control group reached high and average levels against $76.3 \%$ at the beginning of the experiment. 